\title{
Is control through utilization a cost effective Prosopis juliflora management strategy?
}

\author{
Tewodros T. Wakie ${ }^{1,2}$, Dana $\mathrm{Hoag}^{3}$, Paul H. Evangelista ${ }^{2}$, Matthew Luizza ${ }^{1,2}$, Melinda \\ Laituri $^{4}$ \\ ${ }^{\mathbf{1}}$ Graduate Degree Program in Ecology, Colorado State University, Fort Collins, Colorado 80523 \\ USA. ${ }^{2}$ Natural Resource Ecology Laboratory, Colorado State University, Fort Collins, Colorado \\ 80523 USA. $^{3}$ Department of Agricultural and Resource Economics, Colorado State University, \\ Fort Collins, Colorado 80523 USA. ${ }^{4}$ Department of Ecosystem Science and Sustainability, \\ Colorado State University, Fort Collins, Colorado 80523 USA.
}

Corresponding author: Tewodros Wakie. Tel: 970-491-1604.

E-mail address: tewodros@rams.colostate.edu

\begin{abstract}
The invasive tree Prosopis juliflora is known to cause negative impacts on invaded ranges. High $P$. juliflora eradication costs have swayed developing countries to follow a new and less expensive approach known as control through utilization. However, the net benefits of this new approach have not been thoroughly evaluated. Our objective was to assess the economic feasibility of selected $P$. juliflora eradication and utilization approaches that are currently practiced in one of the severely affected developing countries, Ethiopia. The selected approaches include converting $P$. juliflora infested lands into irrigated farms (conversion), charcoal production, and seed flour production. We estimate the costs and revenues of the selected $P$.
\end{abstract}


juliflora eradication and utilization approaches by interviewing 19 enterprise owners. We assess the economic feasibility of the enterprises by performing enterprise, break-even, investment, sensitivity, and risk analyses. Our results show that conversion to irrigated cotton is economically profitable, with Net Present Value (NPV) of 5,234 US\$/ ha over 10 years and an interest rate of $10 \%$ per year. Conversion greatly reduces the spread of $P$. juliflora on farmlands. Managing $P$. juliflora infested lands for charcoal production with a four-year harvest cycle is profitable, with NPV of 805 US\$/ ha. However, the production process needs vigilant regulation to protect native plants from exploitation and caution should be taken to prevent charcoal production sites from becoming potential seed sources. Though flour from P. juliflora pods can reduce invasions by destroying viable seeds, flour enterprises in Ethiopia are unprofitable. Conversion and charcoal production can be undertaken with small investment costs, while flour production requires high investment costs. Introducing new changes in the production and management steps of $P$. juliflora flour might be considered to make the enterprise profitable. Our study shows that control through utilization may be a viable $P$. juliflora management strategy under the right environmental setting.

Key words: animal feed, charcoal, control through utilization, irrigated farming, $P$. juliflora, profitability 


\section{Introduction}

Prosopis juliflora is a fast growing tree that is native to frost free tropical regions of Peru and/or Central America (Burkart, 1976; Pasiecznik et al., 2001, Alban et al., 2002). In the 1970's it was introduced to East African countries through collaborative efforts of governments and international development organizations (Coppock, 2005). It was primarily introduced to rehabilitate degraded soils, to supply firewood and fodder and to combat desertification (Zollner, 1986; Shackleton et al., 2014). However, the species rapidly naturalized and expanded into new locations, where it was neither anticipated nor desired. Prosopis taxa, which comprise 44 species have spread into a large number of semi-arid and arid countries worldwide including India, Pakistan, Iraq, Kenya, South Africa, Australia, Dominican Republic, Mexico, Venezuela and the United States (Burkart, 1976; Shackleton et al., 2014). The invasive P. juliflora plant widely occurs in Ethiopia's Afar region where it currently occupies an estimated 360,500 ha of arid and semi-arid lands (Wakie et al., 2014).

The purpose of this study is to compare management strategies that aim to eradicate the species with those that try to utilize it. Since $P$. juliflora is one of the controversial plants that possess both beneficial and harmful traits, eradication might not be the best option. For example, Kenyan women benefited from easily available $P$. juliflora firewood, while Kenyan herders and farmers often experience the adverse impacts of $P$. juliflora on native plants and associated control costs (Mwangi and Swallow, 2008). The species has several documented uses, both in its native and introduced ranges. In its native range, the species is exploited for human food, animal feed, medicine, timber, honey and energy products (Pasiecznik et al., 2001; Felker, 2005). In India, the species is grown for firewood, charcoal, and generating electric power (Gupta, 1985; Sato, 2013). The species has potential as an agroforestry plant (Singh, 1995), and as a biotic 
carbon pool (Geeising et al., 2000). In Ethiopia, P. juliflora is widely used for animal feed, firewood and charcoal production purposes (Admasu, 2008), but it is unexploited for human food, honey, timber, and electric power production purposes.

Despite its beneficial uses, the species poses a threat to native ecosystems, pastoralism and dry-land farming. The negative impacts of $P$. juliflora include loss of biodiversity (Schachtschneider and February, 2013), reduction of water resources (Gorges and Willgen, 2004; Scott et al., 2006), degradation and loss of rangelands and farmlands (Zimmerman et al., 2006), mortality and decreased livestock health due to high intake of toxic seed pods ${ }^{1}$ (Tabosa, 2006; Admasu, 2008), and high clearing costs on farmlands and rangelands (McConnachie et al., 2012). Efforts to control Prosopis species around the world, particularly by mechanical and chemical means, have been expensive and ineffective (McConnachie et al., 2012; CSIRO, 2013; Sato, 2013). As a result strategies that aim to minimize costs and maximize economic benefits are being sought in several developing countries. For instance, a strategy of managed utilization, controlling through utilization and eradication by utilization, has been advocated in Ethiopia, Nigeria, and Kenya (Borokini and Babalola, 2012; Tessema, 2012; Wakie et al., 2012). These utilization schemes are promoted in developing countries because they create new income opportunities for the affected communities, while positively contributing towards the control and management of the invasive species. Biological and mechanical controlling approaches, which incur higher costs, are the least preferred options in most developing countries (Shackleton et al., 2014).

While much of the management emphasis on invasive species might be oriented towards eradication, people in developing countries have generated new incomes by exploiting the

\footnotetext{
${ }^{1}$ Animals feed on $P$. juliflora seed pods especially in drought conditions. However, its leaves are not palatable. In Ethiopia, animal feed products containing up to $20 \%$ P. juliflora flour are considered safe.
} 
invasive $P$. juliflora trees. Rural households in developing countries have increased their average income by growing and managing $P$. juliflora trees for wood energy (e.g., Sato, 2013). Common P. juliflora control and management practices include burning, digging out stumps, thinning, pruning, and harvesting (Pasiecznik et al., 2001; Njoroge et al., 2012; Wakie et al., 2015). The decision to eradicate $P$. juliflora or to manage it for different income generating purposes may depend on its location. For instance, near water sources where irrigation is possible, farmers choose growing agricultural crops over $P$. juliflora. Moreover, in marginal lands where waterintensive agriculture is not possible, farmers choose growing $P$. juliflora over agricultural crops (Sato, 2013).

Agro-pastoralists in eastern Ethiopia use $P$. juliflora firewood in their households (Haji and Mohammed, 2013). Managing P. juliflora trees for firewood production can be profitable. For instance, in India, a $P$. juliflora fuel-wood plantation, that was managed with a six-year harvest cycle was found to be profitable with a Net Present Value (NPV)= 4,040 Rupees/ ha (Gupta, 1985). In its native range, growing Prosopis for timber production with a thirty-year harvest cycle, was found to be profitable (net profit = 9,777 US\$/ ha; Felker, 1999); however, the practice of harvesting trees at a younger age has restricted $P$. juliflora timber production in Ethiopia. In Afar (Ethiopia), transporting charcoal is cheaper than transporting fuel-wood logs. Thus, more people in Afar are involved in P. juliflora charcoal business than P. juliflora firewood business.

Existing $P$. juliflora eradication and utilization practices in Ethiopia include conversion of $P$. juliflora invaded lands into irrigated agriculture, charcoal production, and flour production (Admasu, 2008, Wakie et al., 2012). Non-governmental organizations (NGOs) working in Afar have in the past formed cooperatives that produced and sold $P$. juliflora charcoal and flour 
produced from its seed pods (Admasu, 2008). Prosopis juliflora charcoal, grown and produced in Afar, is currently distributed and sold in major Ethiopian cities including Addis Ababa and Mekelle (Bekele and Girmay, 2013). Flour, which is used as animal feed, is produced by crushing and milling $P$. juliflora seed pods.

Though several $P$. juliflora utilization and eradication methods are practiced in Ethiopia, we could not find any published studies that analyzed and compared their economic profitability. Identifying and implementing economically feasible $P$. juliflora management strategies is essential for developing countries, as biological and mechanical approaches for controlling its spread are expensive and largely inaccessible. The objectives of our study are to: a) identify $P$. juliflora eradication and utilization approaches used in Ethiopia, b) describe the production and management steps of the identified practices, and estimate all costs and revenues; and c) assess the economic viability of these $P$. juliflora eradication and utilization approaches through income, income sensitivity and risk.

\section{Methods}

\subsection{Study Site}

The study was conducted in Amibara and Gewane woredas (counties) of southern Afar, northeastern Ethiopia (Figure 1). The majority of the Afar people are pastoralists and their main livelihood is based on rearing livestock. The region's agro-ecology is semi-arid in the south, arid in the center, and desert in the north and north-east. Elevation in Afar ranges from $125 \mathrm{~m}$ below sea level to $2,870 \mathrm{~m}$ above sea level. The mean annual precipitation of the study site is $580 \mathrm{~mm}$, while the mean annual temperature is $26.6^{\circ} \mathrm{C}$. Afar faces recurrent natural drought and intermittent flooding from the Awash River. Recent policies of the central government (e.g., for 
agriculture-led industrialization, growth and transformation) encourages the Afar people to minimize their mobility and practice farming. Several government and privately owned largescale farms are present in the study site. Farming is mostly conducted by irrigating the fields using water from the Awash River. Rain-fed farming is not practiced in the study site due to the lack of precipitation and high rate of evapotranspiration. The region contains the largest area of $P$. juliflora infestation in Ethiopia. In Afar, $P$. juliflora has extensively invaded the flat lands along the Awash River and the Alledeghie Plain, an extensive grassland area located in Amibara woreda, northern Afar and the Somali region (Figure 1).

\subsection{Data Collection}

Based on previous $P$. juliflora research findings, we identified one eradication and three utilization strategies practiced in the study site (Wakie et al., 2012; Wakie et al., 2015). The primary eradication practice identified was converting $P$. juliflora infested lands into irrigated farms (irrigated farm enterprise), while the three utilization practices identified were charcoal production (charcoal enterprise), $P$. juliflora seed pod flour production (flour enterprise), and firewood production. Afar communities regularly use $P$. juliflora in their households for firewood; but, we found very few people who sell it as an income source. Since $P$. juliflora firewood production did not exist as an enterprise in our study site, we did not include it in our economic analysis. Our study included 19 enterprises: one cooperative-owned flour enterprise ${ }^{2}$, eight farms, and 10 charcoal enterprises. Cotton and sugarcane are the two principal agricultural crops grown in the study site. We collected data only on small-scale cotton farm enterprises (farm size ranging from one to10 ha). Most small-scale farmers in Afar clear P. juliflora infested

\footnotetext{
${ }^{2}$ We found only one cooperatively owned flour enterprise in the region. We deemed it representative of this new enterprise type after interviewing the cooperative's secretary and accessing their original financial documents.
} 
lands using manual labor, and grow agricultural crops on cleared lands. But, the large-scale farmers, who have sufficient financial capital, indiscriminately clear both the native and invasive P. juliflora trees using heavy machinery. For this reason, our study focused on the small-scale farmers because they see $P$. juliflora both as a challenge and as an opportunity.

We collected data from the field in April and May 2014 by obtaining the names and addresses of the 19 enterprise owners from the kebele representatives. According to the regions' government structure, kebele constitutes the lowest level legal administrative body. We collected data on the production and management steps required to produce three products, i.e., cotton, Prosopis charcoal, and Prosopis flour by interviewing the 19 enterprise owners (see Appendix I for interview questions). Additionally, we collected data on costs (i.e., investment, production, and labor), yields, prices and revenues for all three products from the 19 interviewees. Two of the authors, and one hired multi-lingual Ethiopian professional conducted the interviews. The study design was pre-approved by the Social, Behavioral, and Education Research Institutional Review Board at Colorado State University (Protocol \# 14-5049H).

\subsection{Data Analysis}

Based on the survey results, we estimated costs and revenues for the three enterprise types, prepared enterprise budgets, and performed enterprise, investment, break-even, sensitivity, and risk analyses. Large initial costs occurring at the establishment of an enterprise were amortized (Sharp et al., 2002). For the purpose of estimating costs of farm and charcoal enterprises, we assumed the lifetime of machineries and equipment to be 10 years, and their salvage values to be $10 \%$ of their purchase prices. For the more expensive flour enterprise, we assumed the lifetime of machineries to be 20 years, and the salvage value to be $10 \%$ of purchase price. The lifetime of 
machinery and equipment, and their salvage values used in our analysis were confirmed by interviewees to be representative and reasonable. We calculated machinery and equipment depreciation for all enterprises using the straight line method. We used $10 \%$ interest rates in all of our calculations as this rate was used by Ethiopian banks in most long-term loans. Annual investment cost was obtained by adding annual depreciation and annual interest cost. The annual interest cost (I) was calculated using the equation:

$I=[($ Purchase price + Salvage value $) / 2] * i ;$ where $\mathrm{i}=10 \%$

We calculated gross margins by subtracting operating costs from revenues. Break-even prices were obtained by dividing total costs with expected yields, while break-even yields were obtained by dividing total costs with output prices (Kay et al., 2012). We assessed the profitability of enterprises by projecting cash flows for 10 years, and computing Net Present Values (NPV; Brown and Kwansa, 1999; Connor, 2006; Stille et al., 2011). In NPV analysis, all future costs and benefits are discounted to the present value, permitting easy comparisons of policy or management alternatives (Boardman et al., 2010). Projects with positive NPVs are profitable, while projects with negative NPVs are unprofitable. For a given discount rate (r), time in years $(t)$, project life in years $(n)$, total revenue per year $(R t)$ and total expenses per year (Et), the total Net Present Value (US\$/ ha) over the life of an investment (T) is calculated using the following equation:

$$
N P V_{T}=\sum_{t=0}^{n}(R t-E t) .(1+r)^{-t}
$$


We performed sensitivity tests for all enterprise types by making $\pm 20 \%$ changes in investment costs, gross revenues (prices and yields), and interest rates. The sensitivity tests were conducted to investigate the relative contribution of each economic variable to the profit, and to assess the vulnerability of each enterprise to changes in input costs. Sensitivity tests show how the profit changes ceteris paribus of the variables' changes. We used tornado diagrams (tornado charts) to visualize sensitivity test results.

We analyzed and ranked the outcomes when including risk for the three enterprise types using Simetar@ software (Richardson et al., 2008). We selected prices, yields, fixed costs, and operating costs as stochastic variables. We estimated the means and standard deviations of the selected variables using our data and secondary sources (Table 1). We calculated gross margin values, for all enterprise types, by simulating the stochastic variables one-hundred times (normal distributions with means and standard deviations). We generated cumulative distribution functions (CDFs) of the gross margin values, and subjected the CDFs to first- (FSD) and second(SDD) order Stochastic Dominance tests, which are concepts used for ranking risky alternatives (Hadar and Russell, 1969). The decision rule specifies that, for non-crossing CDFs, one distribution dominates another for any risk preference by a decision maker, whether they be risk averse, risk neutral or risk loving. If CDFs intersect, then second-order stochastic dominance can be used to rank distributions, with the assumption that the decision maker is risk averse (Hadar and Russell, 1969; Richardson, 2014). Distributions cannot always be ranked, but when they can, Stochastic Dominance is a valuable tool because it ranks different options for risk and returns without the need to measure individual risk preferences of the decision makers that will be considering these production alternatives. When distributions cannot be ranked with Stochastic Dominance, they can be ranked with other methods that require more information about the 
unique risk preferences of the decision makers. We describe in the results where first or second degree stochastic dominance are effective. In the case of FSD, we are able to state that farmers that consider risk and income will prefer one of the three management options to all others. In the case of SDD, we can state that anyone that is risk averse would prefer one of the options to the other two. Since risk and resilience are of paramount concern in developing regions, this information helps assure that a risky, but profitable management option is not being recommended without stating so.

\section{Results}

\subsection{Conversion}

Conversion is usually practiced on flat lands near the Awash River where the land is suitable for irrigated farming. Prosopis juliflora infested lands are converted into irrigated cotton, onion, and corn farms. The production and management steps undertaken for the widely grown cotton crop include clearing invaded lands, digging out stumps and roots, burning (charcoal making is optional), land preparation (ploughing, grading, leveling and ridging), seed sowing, weeding, watering, applying pesticides, guarding, picking cotton, packaging, storing, and transporting the product to Awash market (interview questions 1- 4 \& 6 -11, Appendix I). New P. juliflora seedlings that regenerate on cleared lands are regarded as normal weeds and controlled by regular land preparation and weeding practices. Cotton is grown on annual basis over a 10-month period. After cotton is harvested the remaining stalk is left for the Afar livestock to freely browse. Small-scale farmers get the land preparation work done through contractual agreements with large-scale farmers in the study site. The average yield of cotton in the study site was 36 
quintal/ ha, and one quintal of raw cotton was sold for 61.86 US\$ (1,200 Birr $\left.{ }^{3}\right)$ at the Awash market (interview question 11; Appendix I). Cotton is grown by removing P. juliflora and/or the native vegetation. Farmers reported that growing cotton on $P$. juliflora cleared lands can increase its yield by 27\% (10 quintal/ ha/ year) in the first five years (interview question 3; Appendix I).

Investment cost needed to grow cotton on one ha of $P$. juliflora cleared land is 53 US\$ (Table 1). Growing cotton with own machinery and at a larger scale (100 ha of land on average) requires large initial investment, worth 136,521 US\$. Detailed economic analysis is done only for small-scale farms, which were the focus of this study. The gross margin for converting $P$. juliflora infested land into irrigated cotton farm in southern Afar was found to be 508 US\$ (Table 1). Enterprise budgets and investment costs for all the studied $P$. juliflora eradication and utilization options are shown in Appendix II. Our investment analysis, based on 10 years of projected returns and expenses, showed that the investment can be profitable with a Net Present Value (NPV) of 5,234 US\$/ ha (Table 1). The NPV values for conversion remained above zero throughout the ten projected years (Figure 2). The break-even price was 48 US\$/ quintal, while the break-even yield was 28 quintal/ ha. Sensitivity tests using a tornado diagram showed that conversion is sensitive to gross revenue, slightly sensitive to interest rate, and less sensitive to initial investment (Figure 3). The risk analyses shows that conversion has first-order stochastic dominance (preferred by all risk preference types) over flour, while charcoal has second-order stochastic dominance (preferred by all risk averse decision makers) over conversion (Figure 4).

\subsection{Prosopis Charcoal}

\footnotetext{
${ }^{3}$ Birr is the unit of currency used in Ethiopia. In April and May 2014, 1US\$ was equivalent to 19.4 Ethiopian Birr.
} 
Prosopis juliflora infested lands that are currently unsuitable for conversion (e.g., due to inaccessibility to irrigated water or due to high flood risks) are typically exploited for charcoal. In the study site, most of the charcoal is also produced from $P$. juliflora trees growing in communal lands. Charcoal is produced near tree harvesting sites using the earth-mound-kiln method. Charcoal producers (usually Afar men or women with traditional land-use rights) produce charcoal by hiring immigrant labor ${ }^{4}$. The charcoal production and management steps include felling trees, debranching, cutting wood into smaller pieces (the remaining leaves and branches are usually burned), drying wood, gathering dried wood in one location and pilling it, covering pilled wood with soil and tree leaves, lighting the pilled wood and closely monitoring the carbonization process (interview questions 1, $2 \& 4$; Appendix I). When carbonization is complete, the produced charcoal is cooled, packed using polypropylene bags, and temporarily stored at the production site (interview question 4; Appendix I). The average charcoal yield obtained in one production cycle is 150 bags. On average, one bag of $P$. juliflora charcoal weighs $25 \mathrm{~kg}$. All charcoal making steps, from harvesting to packaging, are completed within one month. Charcoal distributers, who also absorb the loading and unloading fees, drive to the production site and buy charcoal at an average price of $2.58 \mathrm{US} \$ /$ bag. Charcoal producers reported that, on average, one hectare of $P$. juliflora infested land can yield 450 bags of charcoal every four years (interview question 4; Appendix I).

We performed the economic analysis using this average yield (i.e., 450 bags of charcoal/ ha), and assessed the sensitivity of the business to $\pm 20 \%$ changes in charcoal gross revenue, investment cost, and interest rate. The investment cost needed for a charcoal enterprise in southern Afar was 127 US\$ (Table 1). Harvesting occurs on mature $P$. juliflora trees that are

\footnotetext{
${ }^{4}$ Ethiopians from the densely populated Southern Nations, Nationalities, and Peoples' region (SNNP), migrate to sparsely populated areas like Afar to get temporary employment.
} 
freely available. Therefore, we assumed the tree tending costs that occur prior to harvesting trees are zero. Replanting is also not needed as $P$. juliflora trees coppice soon after harvest. However, the coppice stand has to be thinned and pruned to produce sustainable yield. The gross margin of a $P$. juliflora stand that is managed for charcoal production with a four-year harvest cycle was 571 US\$ (Table 1). Our investment analysis showed that a $P$. juliflora charcoal enterprise in southern Afar is profitable with NPV of $805 \mathrm{US} \$ /$ ha $(\mathrm{n}=10$; Table 1). The NPVs in non-harvest years remained below zero (Figure 2). The break-even price was 1.34 US\$/ bag of charcoal, while the break-even yield was 236 bags of charcoal/ ha. The sensitivity tests using a tornado diagram showed that the charcoal enterprise is sensitive to gross revenue, slightly sensitive to interest rate, and less sensitive to initial investment (Figure 3). The charcoal enterprise emerged as the most preferred alternative when risk is considered, with first-order stochastic dominance over flour, and second-order stochastic dominance over conversion (Figure 4).

\subsection{Prosopis Flour}

Flour made from P. juliflora pods is used to feed cattle (both beef and dairy), poultry, sheep, goats, and camels. In the study region, $P$. juliflora produces pods twice a year. The main pod production and harvesting season (locally referred as hagai) occurs in May and June, while the second harvesting season (locally referred as gilal) occurs in October. The production and management steps involved in $P$. juliflora flour production include purchasing pods, drying pods, crushing pods (using mortar and pestles), and milling crushed pods using electric mills (interview question 4; Appendix I). The produced flour is packed using polypropylene bags and sold in the local market at a price of $0.1 \mathrm{US} \$ / \mathrm{Kg}$ (interview question 4, Appendix I). The investment costs needed to start a $P$. juliflora pod milling plant is 12,247 US\$ (Table 1). 
Although the pods are purchased at lower prices, pod drying and crushing costs drive up the total flour production costs. We found that less than $50 \%$ of milling time is allocated for flouring P. juliflora pods. The mills do not process $P$. juliflora pods at full capacity because there is little demand for the product and pods are available only in certain seasons (hagai and gilal). The gross margin of the $P$. juliflora flour producing enterprise in southern Afar was -1,351 US\$ (Table 1). The investment is not profitable with NPV of $-17,905$ US $\$(n=10$; Table 1$)$. The break-even price was $0.47 \mathrm{US} \$$ / Kg of $P$. juliflora flour, while the break-even yield was 31,988 Kg of $P$. juliflora flour/ year. Increasing the production level alone did not make the enterprise profitable unless pod processing costs were highly reduced. Unlike conversion and charcoal, $P$. juliflora flour enterprise is sensitive to initial investment, slightly sensitive to gross revenue, and less sensitive to interest rate (Figure 3). Both charcoal and conversion have first-order stochastic dominance over flour, making it the most risky alternative (Figure 4).

\section{Discussion}

We compared the best $P$. juliflora eradication approach, conversion, with two utilization approaches, charcoal and flour. Converting $P$. juliflora infested sites into irrigated farms (conversion) resulted in the highest NPV. However, conversion can take place only on sites that

are close to water sources, and sites that are edaphically and topographically suitable for irrigated farming. Government owned irrigation projects in Afar regularly maintain irrigation channels and dykes in the study site. But, broken and poorly maintained dykes may put some farm enterprises under high flood risk (personal observation). Furthermore, conversion was inferior to utilization for charcoal when risk is considered (Figure 4). 
Prosopis juliflora is a nitrogen fixing plant that improves soil nutrient conditions (Tiedemann and Klemmedson, 1973; Felker, 2009; Ndhlovu et al., 2011) and known to ameliorate saline soils (Singh et al., 2011). Thus, the $27 \%$ additional yield reported by farmers who grow cotton on $P$. juliflora cleared lands (see section 3.1) may be due to the soil improving effects of the invasive P. juliflora plant. This new income, not used in our economic analysis, amounts to 139 US\$/ ha in a single year, and 695 US\$/ ha in five years (interest not included). Thus, farmers who participate in conversion can get additional revenue and a competitive advantage over nonparticipating farmers. We do not advocate for large-scale removal of forests and expansion of irrigated farms in the study site as this creates disturbance and facilitates the expansion of invasive plants (Wakie et al., 2015). However, our results show that converting infested sites into irrigated farms is an effective $P$. juliflora eradication option that is economically viable, where irrigation is feasible.

Our findings also show that managing $P$. juliflora infested sites for charcoal production purposes is economically feasible. Studies conducted in India also suggest that making charcoal from P. juliflora wood is profitable (Gupta, 1985; Stille et al., 2011). Charcoal yield can be considerably increased by introducing more efficient carbonization, torrefaction, and densification techniques (e.g., Adam, 2009; Chen et al., 2015). Improving charcoal yield can increase the gross margin of charcoal enterprises in Afar and make charcoal business even more profitable. However, we do not suggest planting new $P$. juliflora seedlings for charcoal making purposes as this may hasten the spread of $P$. juliflora in Afar. One of the challenges facing the charcoal enterprise is ensuring that charcoal is produced only from P. juliflora trees, not from the native plants ${ }^{5}$. Caution should also be taken to prevent charcoal forests from becoming potential

\footnotetext{
${ }^{5}$ Current legislations indicate that producing charcoal from native trees is illegal in Ethiopia. Native trees are legally harvested for charcoal making in rare occasions (with special permits).
} 
seed sources for $P$. juliflora spread. Charcoal policies (e.g., production, transportation) that seem to be lacking in the country (Bekele and Girmay, 2013) also need to be adjusted to account for the sustainable growth of the charcoal business in the region.

Making flour from $P$. juliflora pods can prevent new invasions by destroying viable seeds. However, the business was not economically viable under the current management practices implemented in southern Afar. The reasons include high initial investment costs, high pod processing costs (e.g., drying, crushing), and poor marketing practices. As a result, the major flour producing cooperative in southern Afar has shifted to milling food grains in place of $P$. juliflora pods. New ideas and practices should be introduced to make flour enterprises profitable. Reducing the initial investment cost, which was also the sensitive economic variable, may make the enterprise profitable. Investment costs can be reduced through owning and using flour mills in groups rather than individually. Other needed steps may include adoption of new marketing strategies (e.g. selling products at Awash and Addis Ababa markets), reducing pod drying and crushing costs, and changing the product type. In Kenya, for instance, the value of $P$. juliflora flour was highly improved by supplementing it with antiemetic medicines, converting it into feed blocks, and marketing the product as best animal feed that controls worms and increases livestock productivity (Syomiti et al., 2015). Flour enterprises in Ethiopia need support from research organizations, especially on nutritional values, chemical compositions, and toxicity levels of $P$. juliflora pods. Subsidizing flour producers should also be considered as contribution towards the control and eradication of this highly invasive plant.

Our profitability analyses clearly identified conversion as the best management alternative that gives high NPV. However, irrigation is possible only in limited locations and our risk analyses ranked charcoal production as the least risky alternative. An individual, who chooses 
conversion, will likely make a profit in most production seasons; but, may occasionally lose or record a very high profit (Figure 4). Conversion is a suitable option for risk-taking individuals. Conversely, an individual, who engages in charcoal production, makes less profit than a cotton farmer. However, it is unlikely for charcoal producers in our study site to register a loss. Charcoal production is the most suitable alternative for risk-averse individuals (second-order Stochastic Dominance). Both of our NPV and risk analyses results ranked flour production as the least preferred alternative. However, appropriate policy and management interventions could make flour production profitable. Our overall economic analysis demonstrates that control through utilization is one of the effective and economically feasible $P$. juliflora management strategies currently accessible to developing countries. This novel approach has a potential to be used as alternative invasive species control strategy worldwide including United States. Finally, our results are based off of farmer interviews. These results need to be corroborated through research, especially in the long run.

\section{Conclusions}

The main $P$. juliflora eradication and utilization approaches practiced in Ethiopia include converting infested lands into irrigated farms, charcoal making, and production of flour from $P$. juliflora pods. We found converting infested lands into irrigated farms (conversion) to be the highly profitable $P$. juliflora eradication technique. In addition to providing economic benefits to farmers, conversion ensures total removal of $P$. juliflora from agricultural lands. However, lands allotted for conversion need to be accessible and suitable for irrigated farming. Conversion has high economic risk compared to charcoal production. Managing $P$. juliflora infested lands for charcoal production with a four-year harvest cycle is an economically viable utilization 
technique. However, caution must be taken to stop the production sites from becoming potential P. juliflora seed sources, and to prevent native plants from illegal exploitation. Regional and national policies, particularly those that deal with $P$. juliflora charcoal production and transport, should be strengthened for the charcoal enterprise to grow. Producing $P$. juliflora flour prevents the expansion of new invasions by destroying viable seeds. However, $P$. juliflora flour producing enterprises are not economically profitable under the current management practices. Subsidies, enhanced products, and new marketing strategies may be considered to make flour enterprises profitable. Controlling the spread of the invasive $P$. juliflora through its utilization can be a costeffective management strategy under the right environmental setting.

\section{Acknowledgments}

We thank Mr. Seid Mohammed for facilitating the field data collection in Ethiopia. Tewodros Wakie would like to thank his family for their support during manuscript preparation. Tewodros and Matthew Luizza acknowledge financial support from the National Needs Fellowship program of the National Institute of Food and Agriculture, U.S. Department of Agriculture (Award Number- 2010-03280). 


\section{References}

Adam, J.C., 2009. Improved and more environmentally friendly charcoal production system using a low-cost retort kiln (Eco-charcoal). Renewable Energy 34: 1923-1925.

Admasu, D., 2008. Invasive plants and food security: the case of Prosopis juliflora in the Afar region of Ethiopia. Farm Africa, IUCN.

Alban, L., Matorel, M., Romero, J., Grados, N., Cruz, G., Felker, P., 2002. Cloning of elite multipurpose trees of the Prosopis julifloral pallida complex in Piura, Peru. Agroforestry systems 54: 173-182.

Bekele, M., Girmay, Z., 2013. Reading through the charcoal industry in Ethiopia: Production, marketing, consumption and Impact. FSS Monograph No. 9, 104 pp.

Boardman, A., Greenberg, D., Vining, A., Weimer, D., 2010. Cost-Benefit analysis: concepts and practice. Prentice Hall: Fourth Edition, 560 pp.

Borokini, T., Babalola, F., 2012. Management of invasive plant species in Nigeria through economic exploitation: lessons from other countries. Management of Biological Invasions 3(1): 45-55.

Brown, D.O., Kwansa, F.A., 1999. Using IRR and NPV models to evaluate societal costs of tourism projects in developing countries. Hospitality Management 18: 31-43.

Burkart, A., 1976. A monograph of the genus prosopis (leguminosae subfam. mimosoidae). Journal of the Arnold Arboretum 57: 219-249.

Chen, W., Peng, J., Bi, X.T., 2015. A state-of-the-art review of biomass torrefaction, densification and applications. Renewable and Sustainable Energy Reviews 44: 847-866. 
Connor, T., 2006. Net present value: Blame the workmen not the tool. Strategic Change 15: 197204.

Coppock, D.L., Aboud, A.A., Kisoyan, P.K., 2005. Agro-pastoralists' wrath for the Prosopis tree: The case of the Il Chamus of Baringo district, Kenya. Research Brief 05-02PARIMA. Global Livestock Collaborative Research Support Program, University of California Davis, 3 pp.

CSIRO. Available: http://www.csiro.au/Outcomes/Safeguarding-Australia/MesquiteControl.aspx. Accessed: 25 September 2014.

de Wit, M., Crookes, D., van Wilgen, B., 2002. Conflict of interest in environmental management: estimating the costs and benefits of a tree invasion. Biological Invasions 3: $167-178$.

Felker, P., 1999. An investment-based approach to Prosopis agroforestry in arid lands. Annals of Arid Zone 38(3\&4): 385-397.

Felker, P., 2005. Mesquite Flour: New Life for an Ancient Staple. Gastronomica: The Journal of Food and Culture 5(2): 85-89.

Felker, P., 2009. Unusual physiological properties of the arid adapted tree legume Prosopis and their applications in developing countries. In Perspectives in Biophysical Plant Ecophysiology: A Tribute to Park S. Nobel, pp. 221-255. Editors: De la Barrera, E., and Smith, W.

Geesing, D., Felker, P., Bingham, R., 2000. Influence of mesquite (Prosopis glandulosa) on soil nitrogen and carbon development: Implications for global carbon sequestration. Journal of Arid Environments 46: 157-180. 
Görgenes, A., van Wilgen, B., 2004. Invasive alien plants and water resources in South Africa: current understanding, predictive ability and research challenges. South African Journal of Science 100: 27-33.

Gupta, T., 1985. Economics of sylvi-pastoral systems in India. FAO conservation guide 10: 159167.

Hadar, J., Russell, W.R., 1969. Rules for ordering uncertain prospects. The American Economic Review 59(1): 25-34.

Haji, J., Mohammed, A., 2013. Economic impact of Prosopis juliflora on agropastoral households of Dire Dawa administration, Ethiopia. African Journal of Academic Research 8(9): 768-779.

Kay, R., Edwards, W., Duffy, P., 2012. Farm management. McGraw Hill International Edition, $466 \mathrm{pp}$.

McConnachie, M., Cowling, R., van Wilgen, B., McConnachie, D., 2012. Evaluating the costeffectiveness of invasive alien plant clearing: a case study from South Africa. Biological Conservation 155: 128-135.

Mwangi, E., Swallow, B., 2008. Prosopis juliflora invasion and rural livelihoods in the lake Baringo Area of Kenya. Conservation and Society 6(2):130-140.

Ndhlovu, T., Milton-Dean, S., Esler, K., 2011. Impact of Prosopis (mesquite) invasion and clearing on the grazing capacity of semiarid Nama Karoo rangeland, South Africa. African Journal of Range \& Forage Science 28(3): 129-137. 
Njoroge, E., Sirmah, P., Mburu, F., Koeche, E., Mware, M., Chepkwony, J., 2012. Preference and adaptation of Farmer Field School (FFS) Prosopis juliflora management practices: Experiences in Baringo District, Kenya. For. Stud. China 14(4): 283-290.

Pasiecznik, N.M., Felker, P., Harris, P., Harsh, L., Cruz, G., Tewari, J., Cadoret, K., Maldonado, L., 2001. The Prosopis juliflora - Prosopis pallida Complex: A Monograph. HDRA, Coventry, UK, $172 \mathrm{pp}$.

Richardson, J.W., Schumann, K.D., Feldman, P.A., 2008. Simulations \& econometrics to analyze risk. Simetar, inc. College Station, Texas.

Richardson, J.W., 2014. Computer modeling: Policy analysis and simulation. In: Van Alfen, N, Encyclopedia of agriculture and food systems, Vol. 2, pp. 359-374.

Sato, T., 2013. Beyond water-intensive agriculture: Expansion of Prosopis juliflora and its growing economic use in Tamil Nadu, India. Land Use Policy 35: 283-292.

Scott, R., Huxman, T., Williams, D., Goodrich, D., 2006. Ecohydrological impacts of woodyplant encroachment: seasonal patterns of water and carbon dioxide exchange within a semiarid riparian environment. Global Change Biology 12: 311-324.

Shackleton, R.T., Le Maitre, D.C., Pasiecznik, N.M., Richardson, D.M., 2014. Prosopis: a global assessment of the biogeography, benefits, impacts and management of one of the world's worst woody invasive plant taxa. AoB PLANTS 6: plu027; doi:10.1093/aobpla/plu027.

Sharp, R., Caspari, H., Hoag, D., 2002. The cost of growing wine grapes in western Colorado. Web. 27 Jan. 2014. http://www.coopext.colostate.edu/ABM/costofgrowinggrapes02.pdf. 
Singh, G., 1995. An agroforestry practice for the development of salt lands using Prosopis juliflora Leptochloa fusca. Agroforestry Systems 29: 61-75.

Singh, Y., Singh, G., Sharma, D., 2011. Ameliorative effect of multipurpose tree species grown on sodic soils of Indo-Gangetic alluvial plains of India. Arid land research and management 25: 55-74.

Schachtschneider, K., February, E., 2013. Impact of Prosopis invasion on a keystone tree species in the Kalahari Desert. Plant Ecology 214: 597-605.

Stille, L., Smeets, E., Wicke, B., Singh, R., Singh, G., 2011. The economic performance of four (agro-) forestry systems on alkaline soils in the state of Haryana in India. Energy for Sustainable Development 15: 388-397.

Syomiti, M., Hoag, H., Getachew, G., Beatrice, M., Wamae, D., 2015. Medicated Prosopis spp based feed blocks- for anthelmintic efficacy and performance of weaner lambs. Livestock Research for Rural Development. Vol 27, Article \#50. Available: http://www.lrrd.org/lrrd27/3/syom27050.html. Accessed: 2 May 2015.

Tabosa, I., Riet-Correa, M., Barros, S., Summers, B., Simoes, S., Medeiros, R., Nobre, V., 2006. Neurohistologic and Ultrastructural Lesions in Cattle Experimentally Intoxicated with the Plant Prosopis juliflora. Vet Pathol 43: 695-701.

Tessema, Y., 2012. Ecological and economic dimensions of the paradoxical invasive speciesProsopis juliflora and policy challenges in Ethiopia. Journal of Economics and Sustainable Development 3(8): 62-70. 
Tiedemann, A., Klemmedson, J., 1973. Effects of soil on physical and chemical properties of the soil. Journal of range management 26(1): 27-29.

Wakie, T., Evangelista, P., Laituri, M., 2012. Utilization assessment of Prosopis juliflora in Afar region, Ethiopia. Available: http://www.nrel.colostate.edu/projects/csuethiopia/documents/NewsFeed_Wakie_Final.pdf. Accessed: 12 March 2015.

Wakie, T.T., Evangelista, P.H., Jarnevich, C.S., Laituri, M., 2014. Mapping current and potential distribution of non-native Prosopis juliflora in the Afar region of Ethiopia. PLoS ONE 9(11): e112854. doi:10.1371/journal.pone.0112854.

Wakie, T., Evangelista, P., Laituri, M., 2015. (In press). Assessing the distribution and impacts of Prosopis juliflora through participatory approaches. Applied Geography.

Zimmermann, H., Hofmann, J., Witt, A., 2006. A South African Perspective on Prosopis. Biocontrol News and Information 27: 6-9.

Zollner, D., 1986. Sand dune stabilization in central Somalia. Forest Ecology and Management $16: 223-232$. 
Table 1. Initial investment costs, gross margins and Net Present Values (NPVs) for charcoal, irrigated farm (conversion) and flour enterprises in US\$.

\begin{tabular}{l|l|c|c|c}
\hline $\begin{array}{c}\text { Enterprise } \\
\text { Type }\end{array}$ & \multicolumn{1}{c|}{ Unit } & $\begin{array}{c}\text { Investment } \\
\text { Cost }\end{array}$ & Gross Margin & $\begin{array}{c}\text { Net Present Value } \\
\text { (NPV) }\end{array}$ \\
\hline $\begin{array}{l}\text { Irrigated } \\
\text { Farm }\end{array}$ & US\$/ ha / year & 53 & 508 & 5,234 \\
\hline Charcoal & US\$/ ha/ year & 127 & 571 & 805 \\
\hline Flour & US\$/ year & 12,247 & $-1,351$ & $-17,905$ \\
\hline
\end{tabular}

Table 2. Means and Standard Deviations (SDs) of prices, yields, operating costs, and fixed costs.

We used our data and information from secondary sources to estimate the values.

\begin{tabular}{|c|c|c|c|c|c|c|c|}
\hline \multirow{2}{*}{\multicolumn{2}{|c|}{$\begin{array}{c}\text { Stochastic Variables } \\
\text { (Means, SDs) }\end{array}$}} & \multicolumn{6}{|c|}{ Enterprise Types } \\
\hline & & Farm & Unit & Charcoal & Unit & Flour & Unit \\
\hline \multirow[b]{2}{*}{ Price } & Mean & 61.86 & US\$/ Quintal & 2.58 & US\$/ Bag & 0.10 & $\mathrm{US} \$ / \mathrm{Kg}$ \\
\hline & SD & 2.58 & US\$/ Quintal & 0.26 & US\$/ Bag & 0.03 & $\mathrm{US} \$ / \mathrm{Kg}$ \\
\hline \multirow[b]{2}{*}{ Yield } & Mean & 36.00 & Quintal/ ha & 450.00 & Bag/ ha & $7,000.00$ & $\mathrm{Kg}$ \\
\hline & SD & 10.00 & Quintal/ ha & 50.00 & Bag/ ha & $2,000.00$ & $\mathrm{Kg}$ \\
\hline \multirow[b]{2}{*}{ Operating Costs } & Mean & $1,460.82$ & US\$/ ha/ year & 589.12 & US\$/ ha/ year & $2,072.94$ & US\$/ year \\
\hline & SD & 154.64 & US $\$$ / ha/ year & 51.55 & US $\$$ / ha/ year & 77.32 & US\$/ year \\
\hline \multirow[b]{2}{*}{ Fixed Costs } & Mean & 7.63 & US\$/ ha/ year & 18.40 & US\$/ ha/ year & $1,224.74$ & US\$/ year \\
\hline & SD & 2.06 & US\$/ ha/ year & 2.32 & US\$/ ha/ year & 51.55 & US\$/ year \\
\hline
\end{tabular}


Figure 1. Map of the study site. The study was conducted in Amibara and Gewane counties of the Afar administrative region (Ethiopia).

Figure 2. NPV trends of irrigated farm and charcoal enterprises over 10 years (US\$). NPVs for conversion were positive throughout the 10 years, while NPVs for charcoal showed positive values only in harvest years.

Figure 3. Sensitivity test. Sensitivity of irrigated farm, charcoal and flour enterprises to a $\pm 20 \%$ change in gross income, interest rate, and initial investment costs.

Figure 4. Cumulative distribution functions (CDFs). CDFs of profits for irrigated farm, charcoal and flour enterprises in Afar. 


\section{Appendix I}

\section{Interview Questions}

Location:__Date:

Primary Occupation: (Pastoralist, Agro-pastoralist, Farmer, Enterprise Owner)

Gender: (Male / Female)

1. What are the production and management steps required to clear Prosopis, and what time of year do they occur?

1.1

1.2

1.3

1.4

1.5

2. What is the cost of each of these steps? (Define quantity of labor or other inputs used and prices of inputs).

\begin{tabular}{|l|l|l|l|l|l|l|}
\hline No. & $\begin{array}{l}\text { Production \& } \\
\text { Management step }\end{array}$ & $\begin{array}{l}\text { Time of } \\
\text { year }\end{array}$ & Units & Quantity & Unit Cost & Cost \\
\hline 2.1 & & & & & & \\
\hline 2.2 & & & & & & \\
\hline 2.3 & & & & & & \\
\hline 2.4 & & & & & & \\
\hline 2.5 & & & & & & \\
\hline 2.6 & & & & & & \\
\hline 2.7 & & & & & & \\
\hline
\end{tabular}

3. After removing Prosopis would your crop yield go up? (Yes/ No). If yes, indicate the quantity? Answer for all Prosopis control types and competing crops.

4. Do you generate income from Prosopis products? (Yes / No)

If yes, please answer $4.1-4.4$; if no, proceed to 5. Answer yes if you harvest for your own use but do not sell any product.

4.1 What are the income generating Prosopis products that you produce? Give details about yields.

4.2 How much income do you get from each product (Birr/ha/yr)? Where is your market? What are the prices? Give details (If used at home, then specify what you could have sold the product for if you had not used it for home use) 
4.3 What are the production and management steps required to harvest Prosopis?

\begin{tabular}{|l|l|l|l|l|l|l|}
\hline No. & $\begin{array}{l}\text { Production \& } \\
\text { Management step }\end{array}$ & $\begin{array}{l}\text { Time of } \\
\text { year }\end{array}$ & Units & Quantity & Unit Cost & Cost \\
\hline 4.31 & & & & & & \\
\hline 4.32 & & & & & & \\
\hline 4.33 & & & & & & \\
\hline 4.34 & & & & & & \\
\hline 4.35 & & & & & & \\
\hline 4.36 & & & & & & \\
\hline 4.37 & & & & & & \\
\hline 4.38 & & & & & & \\
\hline 4.39 & & & & & & \\
\hline
\end{tabular}

4.4 How do you store or process these products? (Answer for each product sold).

\begin{tabular}{|l|l|l|l|l|l|l|}
\hline No. & Steps & $\begin{array}{l}\text { Time of } \\
\text { year }\end{array}$ & Units & Quantity & Unit Cost & Cost \\
\hline 4.41 & & & & & & \\
\hline 4.42 & & & & & & \\
\hline 4.43 & & & & & & \\
\hline 4.44 & & & & & & \\
\hline 4.45 & & & & & & \\
\hline 4.46 & & & & & & \\
\hline 4.47 & & & & & & \\
\hline 4.48 & & & & & & \\
\hline 4.49 & & & & & & \\
\hline
\end{tabular}

5. Is there any other use of Prosopis that you know about?

6. Would you be willing to convert the Prosopis infested land into other land use types? (Yes/ No) Please give details.

7. What are the pros and cons of converting Prosopis into other land use types?

8. What are the pros and cons of leaving Prosopis instead of clearing it? 
9. What kind of enterprise do you own where the Prosopis is located?

10. What are the costs related to this enterprise? Use the following table to estimate costs.

\begin{tabular}{|l|l|l|l|l|l|l|}
\hline No. & Steps & $\begin{array}{l}\text { Time of } \\
\text { year }\end{array}$ & Units & Quantity & Unit Cost & Cost \\
\hline 10.1 & & & & & & \\
\hline 10.2 & & & & & & \\
\hline 10.3 & & & & & & \\
\hline 10.4 & & & & & & \\
\hline 10.5 & & & & & & \\
\hline 10.6 & & & & & & \\
\hline 10.7 & & & & & & \\
\hline 10.8 & & & & & & \\
\hline
\end{tabular}

11. What are the incomes from this enterprise? Indicate product type, price and market location.

12. What are the main problems associated with this enterprise?

13. How much do you feel Prosopis reduces the profit of this enterprise (birr/hectare)? Please explain.

14. What solutions do you suggest, with respect to Prosopis, to make your enterprise more profitable?

15. Is there anything that we didn't ask regarding Prosopis that you would like to share? 


\section{Appendix II}

Irrigated cotton enterprise investment cost for southern Afar (Ethiopia)

Interest rate $10 \%$

Hectare 1

\begin{tabular}{|c|c|c|c|c|c|c|c|c|}
\hline Farm tools & $\begin{array}{l}\text { Unit } \\
\text { price } \\
\text { (Birr) }\end{array}$ & Quantity & $\begin{array}{c}\text { Total } \\
\text { purchase } \\
\text { price } \\
\text { (Birr) }\end{array}$ & $\begin{array}{c}\text { Salvage } \\
\text { value }\end{array}$ & $\begin{array}{c}\text { Useful } \\
\text { life } \\
\text { (Years) }\end{array}$ & Depreciation & Interest & $\begin{array}{c}\text { Annual } \\
\text { cost } \\
\text { (Birr) } \\
\end{array}$ \\
\hline Hand saw & 400 & 1 & 400 & 40 & 10 & 36 & 22 & 58 \\
\hline Axe & 200 & 1 & 200 & 20 & 10 & 18 & 11 & 29 \\
\hline Spade & 90 & 1 & 90 & 9 & 10 & 8 & 5 & 13 \\
\hline Rake & 90 & 1 & 90 & 9 & 10 & 8 & 5 & 13 \\
\hline Machete & 90 & 1 & 90 & 9 & 10 & 8 & 5 & 13 \\
\hline File & 60 & 1 & 60 & 6 & 10 & 5 & 3 & 9 \\
\hline Hoe & 90 & 1 & 90 & 9 & 10 & 8 & 5 & 13 \\
\hline $\begin{array}{l}\text { Total } \\
\text { equipment } \\
\text { investment }\end{array}$ & 1020 & & & 102 & & 92 & 56 & 148 \\
\hline
\end{tabular}

Charcoal enterprise investment cost for southern Afar (Ethiopia) Interest rate $10 \%$

\begin{tabular}{|c|c|c|c|c|c|c|c|c|}
\hline Equipment & $\begin{array}{l}\text { Unit } \\
\text { price } \\
\text { (Birr) } \\
\end{array}$ & Quantity & $\begin{array}{l}\text { Total } \\
\text { purchase } \\
\text { price } \\
\text { (Birr) } \\
\end{array}$ & $\begin{array}{l}\text { Salvage } \\
\text { value }\end{array}$ & $\begin{array}{l}\text { Useful } \\
\text { life } \\
\text { (Years) }\end{array}$ & $\begin{array}{l}\text { Depreciation } \\
\text { (Birr) }\end{array}$ & $\begin{array}{l}\text { Interest } \\
\text { (Birr) }\end{array}$ & $\begin{array}{l}\text { Annual } \\
\text { cost } \\
\text { (Birr) } \\
\end{array}$ \\
\hline Hand saw & 400 & 2 & 800 & 80 & 10 & 72 & 44 & 116 \\
\hline Axe & 200 & 2 & 400 & 40 & 10 & 36 & 22 & 58 \\
\hline Spade & 90 & 2 & 180 & 18 & 10 & 16 & 10 & 26 \\
\hline Rake & 90 & 2 & 180 & 18 & 10 & 16 & 10 & 26 \\
\hline Machete & 90 & 2 & 180 & 18 & 10 & 16 & 10 & 26 \\
\hline Shears & 300 & 2 & 600 & 60 & 10 & 54 & 33 & 87 \\
\hline File & 60 & 2 & 120 & 12 & 10 & 11 & 7 & 17 \\
\hline \multicolumn{4}{|c|}{ Total equipment investment } & & & 221 & 135 & 357 \\
\hline
\end{tabular}


Prosopis flour producing plant investment cost for southern Afar (Ethiopia)

Interest rate $10 \%$

\begin{tabular}{|c|c|c|c|c|c|c|c|c|}
\hline Machine & $\begin{array}{l}\text { Unit price } \\
\text { (Birr) }\end{array}$ & Quantity & $\begin{array}{c}\text { Total } \\
\text { purchase } \\
\text { price (Birr) }\end{array}$ & $\begin{array}{c}\text { Salvage } \\
\text { value }\end{array}$ & $\begin{array}{l}\text { Useful } \\
\text { life }\end{array}$ & $\begin{array}{c}\text { Depreciation } \\
\text { (Birr) }\end{array}$ & $\begin{array}{c}\text { Interest } \\
\text { (Birr) }\end{array}$ & $\begin{array}{l}\text { Annual } \\
\text { cost (Birr) }\end{array}$ \\
\hline $\begin{array}{l}\text { Mill (30 watt } \\
\text { dynamo) }\end{array}$ & 40000 & 1 & 40000 & 4000 & 20 & 1800 & 2200 & 4000 \\
\hline Transformer & 100000 & 1 & 100000 & 10000 & 20 & 4500 & 5500 & 10000 \\
\hline Scale & 15000 & 1 & 15000 & 1500 & 20 & 675 & 825 & 1500 \\
\hline $\begin{array}{l}\text { Store ( for drying } \\
\text { pods and } \\
\text { housing the mill) }\end{array}$ & 80000 & 1 & 80000 & 8000 & 20 & 3600 & 4400 & 8000 \\
\hline Mortar & 1000 & 2 & 2000 & 200 & 20 & 90 & 110 & 200 \\
\hline Pestle & 300 & 2 & 600 & 60 & 20 & 27 & 33 & 60 \\
\hline \multicolumn{6}{|c|}{ Total machinery investment } & 10692 & 13068 & 23760 \\
\hline
\end{tabular}




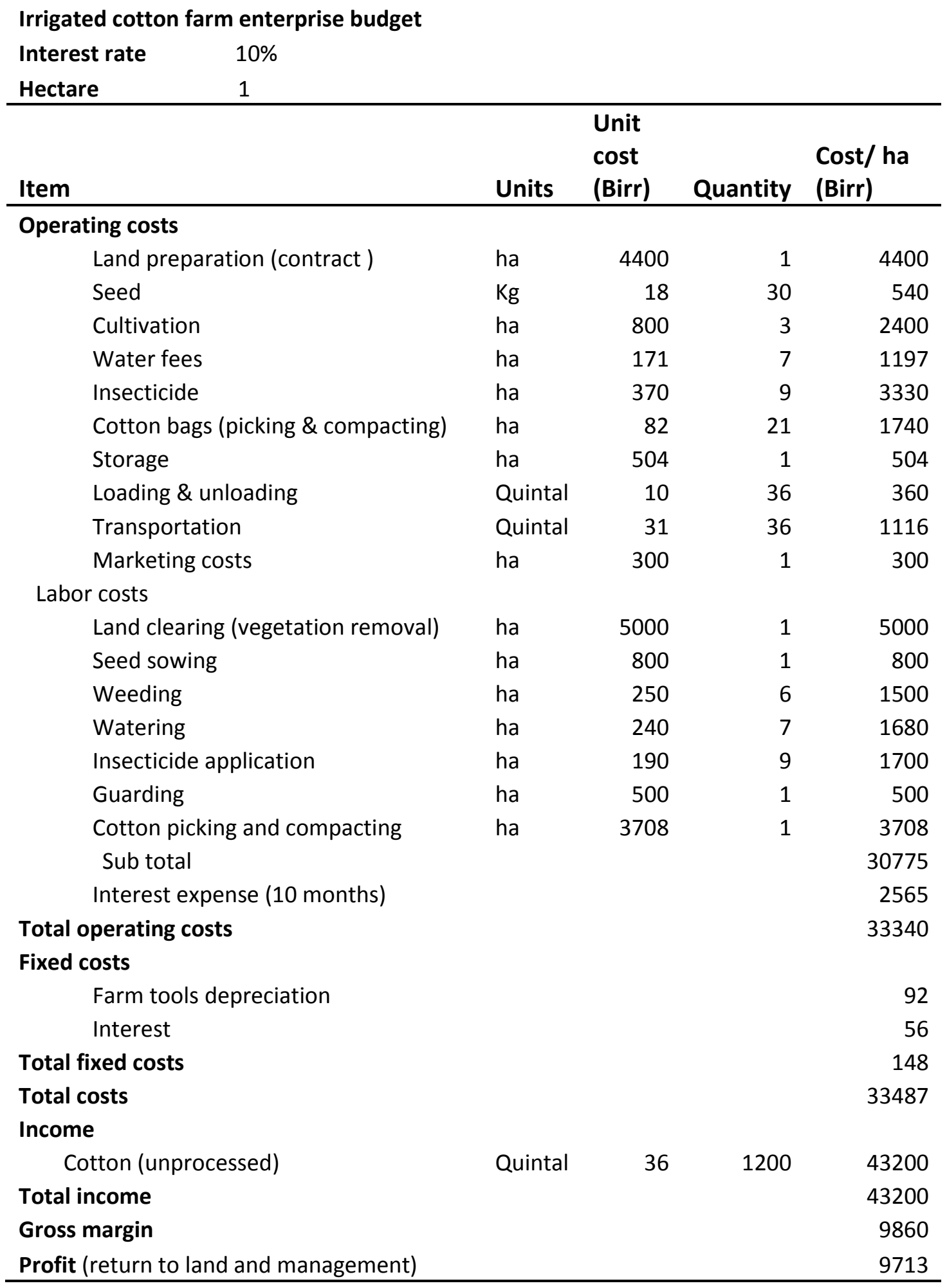


Charcoal enterprise budget (450 bags/ha)

Interest rate $10 \%$

Yield 11.25 ton (450 bags each weighing $25 \mathrm{~kg}$ ) of charcoal with four years rotation

\begin{tabular}{|c|c|c|c|c|}
\hline Item & Units & $\begin{array}{l}\text { Unit } \\
\text { cost } \\
\text { (Birr) }\end{array}$ & Quantity & $\begin{array}{l}\text { Cost per } \\
\text { hectare } \\
\text { (Birr) }\end{array}$ \\
\hline \multicolumn{5}{|l|}{ Operating costs } \\
\hline \multicolumn{5}{|l|}{ Labor costs } \\
\hline Harvesting trees & ha & 4000 & 1 & 4000 \\
\hline Cutting wood into smaller pieces & ha & 2000 & 1 & 2000 \\
\hline Drying and pilling wood & ha & 900 & 1 & 900 \\
\hline Carbonization & ha & 800 & 1 & 800 \\
\hline Cooling and packaging & ha & 300 & 1 & 300 \\
\hline Packaging material & No. & 7 & 450 & 3150 \\
\hline sub total & & & & 11150 \\
\hline Interest expense ( 3 months) & & & & 279 \\
\hline Total operating costs & & & & 11429 \\
\hline \multicolumn{5}{|l|}{ Fixed costs } \\
\hline Equipment depreciation & & & & 221 \\
\hline Interest & & & & 135 \\
\hline Total fixed costs & & & & 357 \\
\hline Total costs & & & & 11785 \\
\hline \multicolumn{5}{|l|}{ Income } \\
\hline Yield (bags of charcoal/ha) & No. & 50 & 450 & 22500 \\
\hline Total Income & & & & 22500 \\
\hline Gross margin & & & & 11071 \\
\hline Profit (return to land and management) & & & & 10715 \\
\hline
\end{tabular}


Prosopis flour enterprise budget for southern Afar (Ethiopia)

Interest rate $10 \%$

\begin{tabular}{|c|c|c|c|c|}
\hline Item & Units & $\begin{array}{l}\text { Unit } \\
\text { cost } \\
\text { (Birr) }\end{array}$ & Quantity & Cost (Birr) \\
\hline \multicolumn{5}{|l|}{ Operating costs } \\
\hline Purchasing pods (fresh weight) & $\mathrm{Kg}$ & 0.5 & 20000 & 10000 \\
\hline Electric cost & month & 700 & 6 & 4200 \\
\hline Packaging material & $\mathrm{Kg}$ & 0.4 & 7000 & 2800 \\
\hline Marketing costs & $\mathrm{Kg}$ & 0.05 & 7000 & 350 \\
\hline Machinery maintenance & No. & 400 & 2 & 800 \\
\hline Labor costs & $\mathrm{Kg}$ & & & \\
\hline Pod drying & $\mathrm{Kg}$ & 0.3 & 20000 & 6000 \\
\hline Pod crushing & $\mathrm{Kg}$ & 0.8 & 12000 & 9600 \\
\hline Packaging costs & $\mathrm{Kg}$ & 0.05 & 7000 & 350 \\
\hline Mill operator & month & 700 & 6 & 4200 \\
\hline Sub total & & & & 38300 \\
\hline Interest expense (6 months) & & & & 1915 \\
\hline Total operating costs & & & & 40215 \\
\hline \multicolumn{5}{|l|}{ Fixed costs } \\
\hline Machinery depreciation & & & & 10692 \\
\hline Interest & & & & 13068 \\
\hline Total fixed costs & & & & 23760 \\
\hline Total costs & & & & 63975 \\
\hline \multicolumn{5}{|l|}{ Income } \\
\hline Prosopis flour & $\mathrm{Kg}$ & 2 & 7000 & 14000 \\
\hline Total income & & & & 14000 \\
\hline Gross margin & & & & -26215 \\
\hline Profit (return to management) & & & & -49975 \\
\hline
\end{tabular}




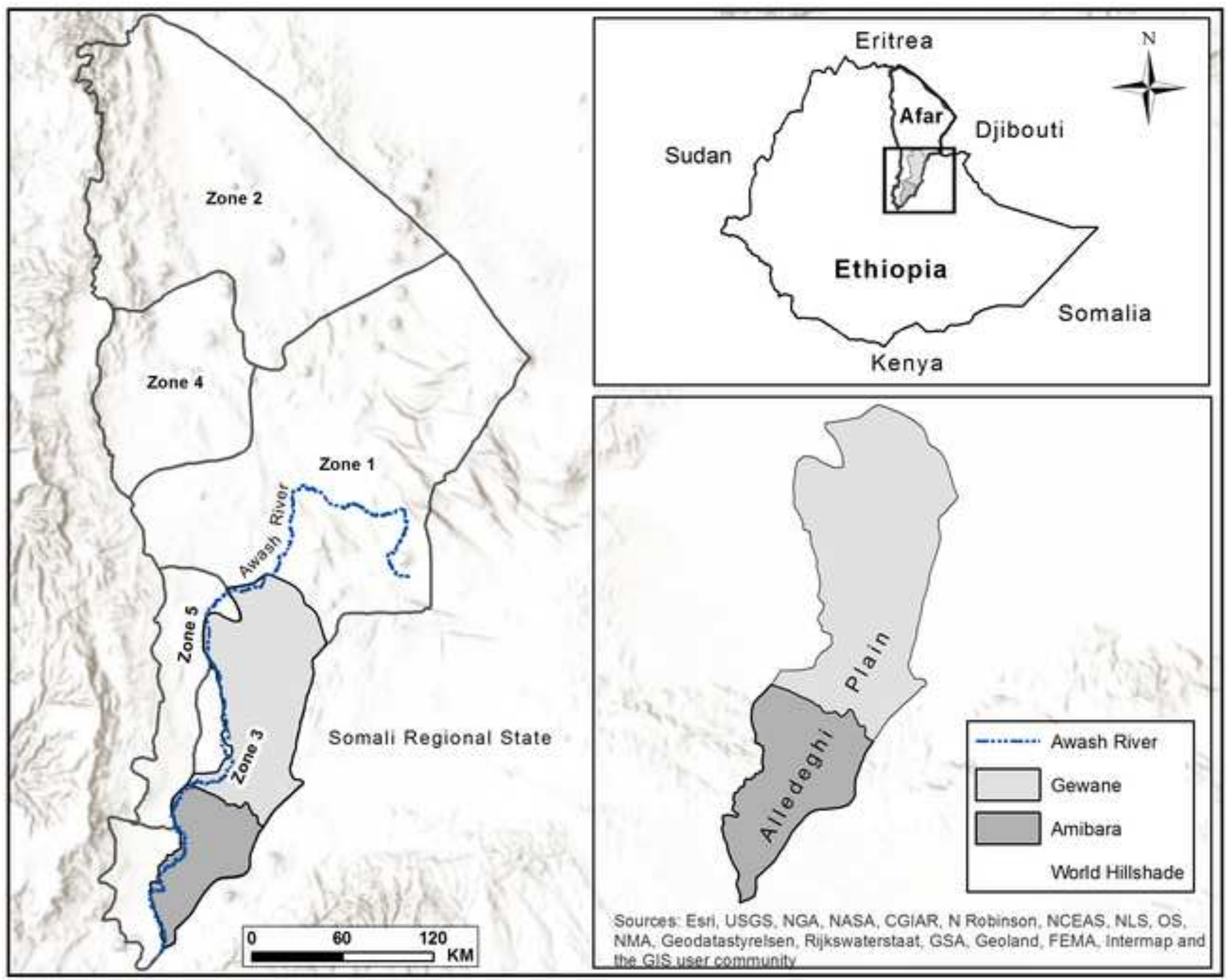




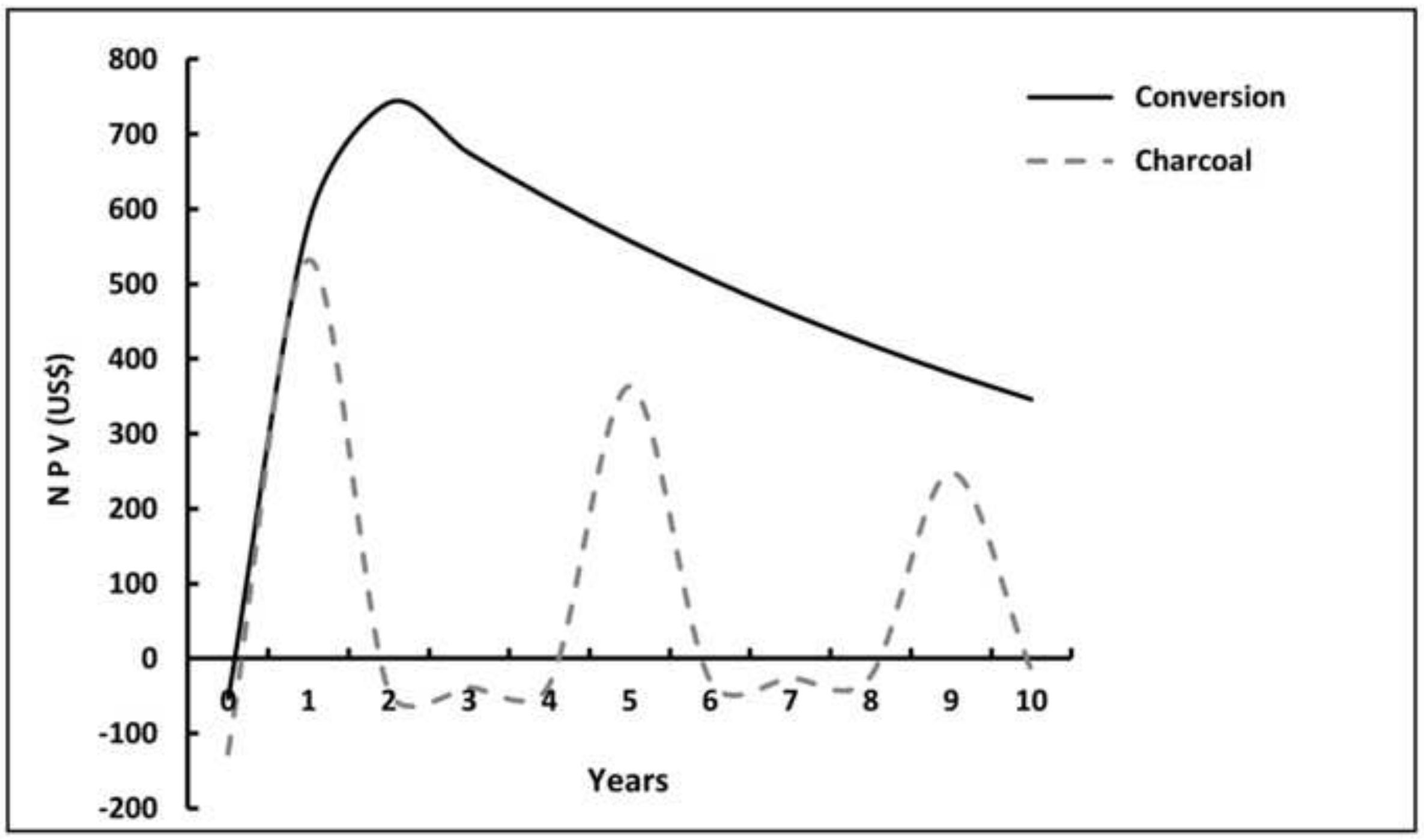


Flour NPV in US\$

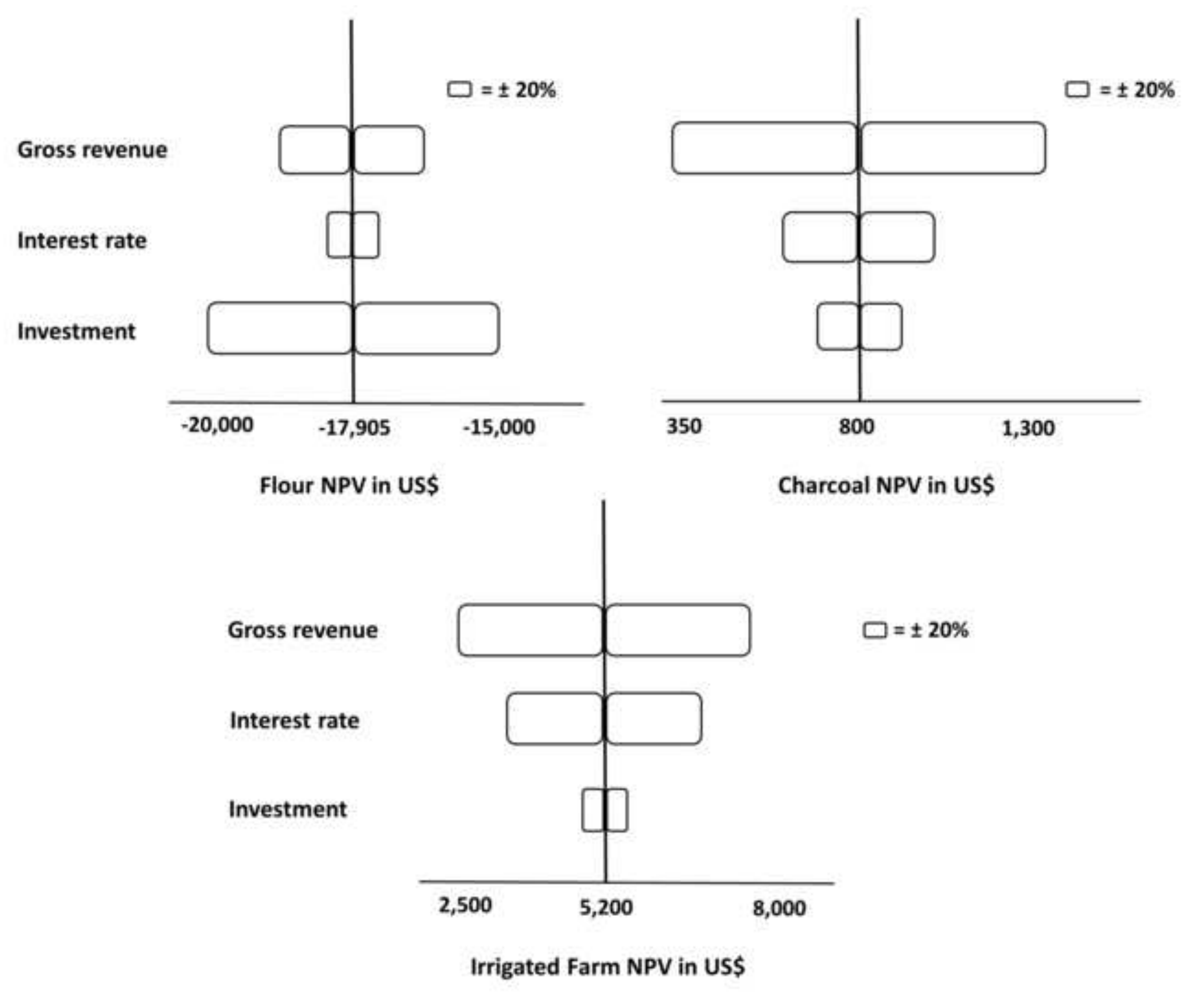

Charcoal NPV in US\$
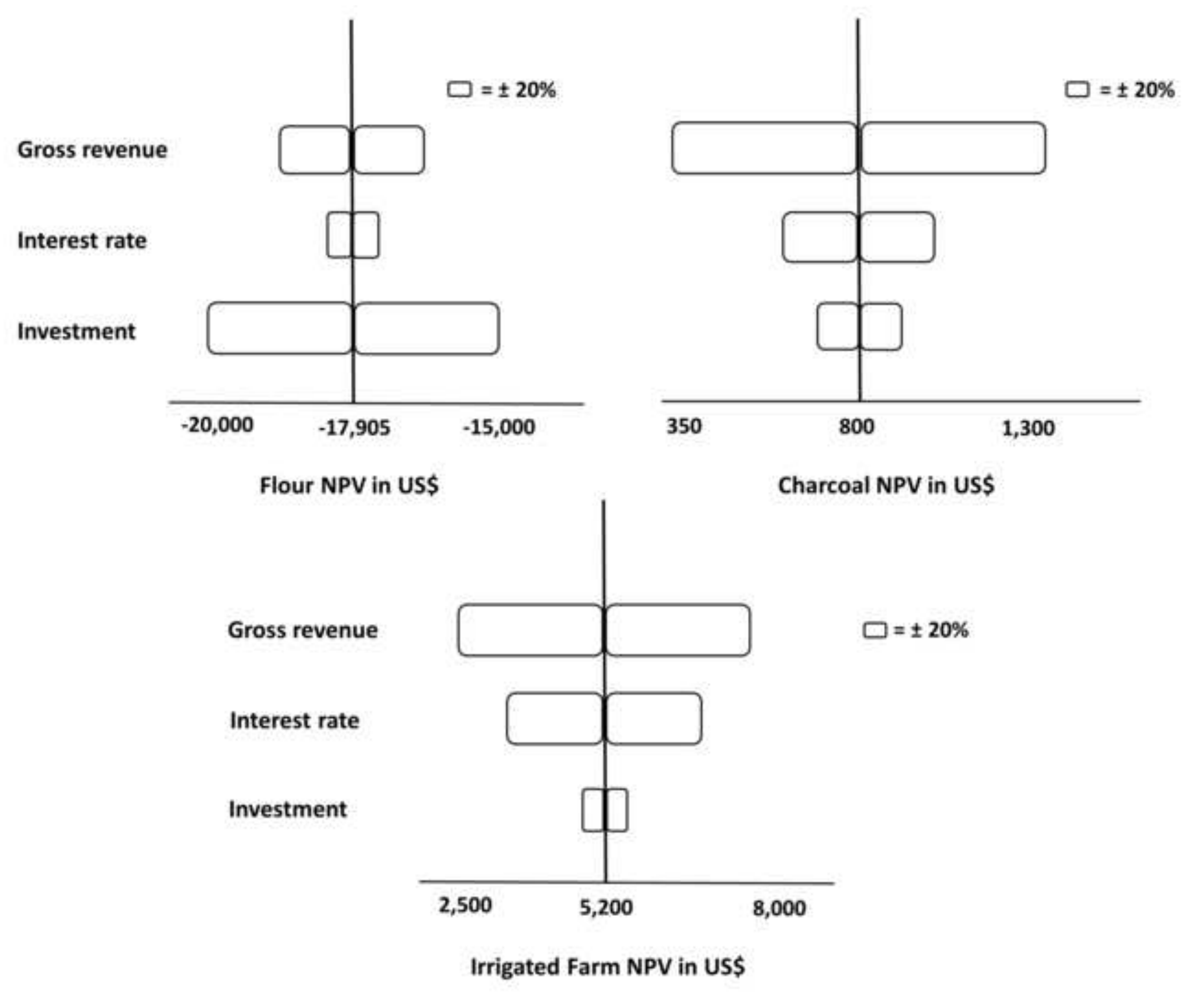

Irrigated Farm NPV in US\$ 


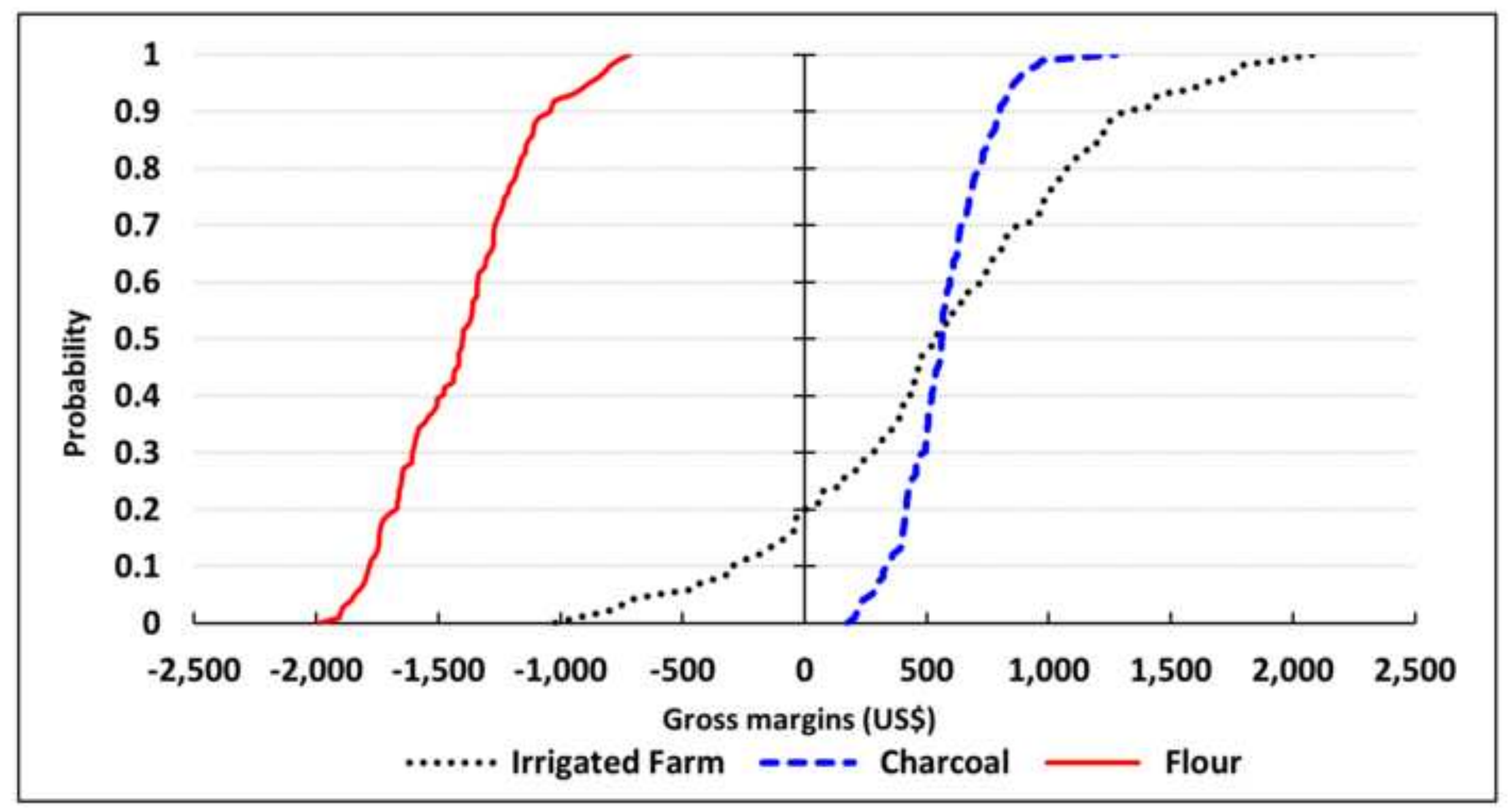

